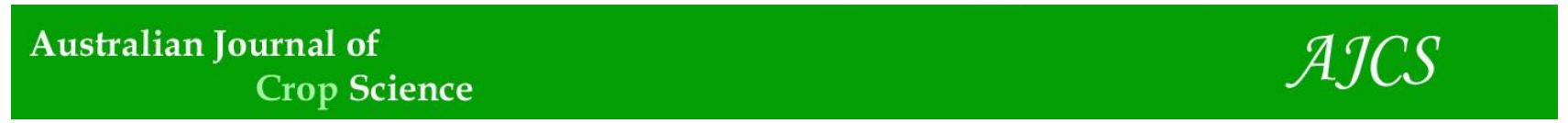

AJCS 14(09):1399-1404 (2020)

ISSN:1835-2707

doi: 10.21475/ajcs.20.14.09.p2394

\title{
Spatial variability of soil physical attributes in sugarcane using different row spacings
}

\author{
Wildon Panziera ${ }^{1}$, Cláudia Liane Rodrigues de Lima ${ }^{1}{ }^{*}$, Jean Michel Moura-Bueno ${ }^{2}$, Eloy Antonio Pauletto ${ }^{1}$ \\ Sergio Delmar dos Anjos e Silva ${ }^{3}$, Luis Carlos Timm ${ }^{1}$, Lizete Stumpf ${ }^{1}$
}

${ }^{1}$ Federal University of Pelotas - Pelotas, Rio Grande do Sul, Brazil
${ }^{2}$ Federal University of Santa Maria - Santa Maria, Rio Grande do Sul, Brazil
${ }^{3}$ Research Center Embrapa Temperate Climate - Pelotas, Rio Grande do Sul, Brazil

* Corresponding author: zete.stumpf@gmail.com

Abstract

The aim of this study was to determine the impact of harvesting traffic by evaluating the spatial variability of soil physical attributes on a clayey Oxisol under sugarcane cultivation using different row spacing. Two areas of sugarcane production (RB855156 genotype) were planted in autumn 2013, both using conventional planting systems. Treatments were either sugarcane cultivated using: (i) single-row spacing (SR) of $1.50 \mathrm{~m}$; or (ii) double-row spacing (DR) of $0.40 \times 1.50 \mathrm{~m}$. Areas using SR spacing occupied a total of 6 ha areas using DR spacing occupied a total of 2 ha. Assessments of soil physical attributes were performed during the summer of 2016 after the second harvest. Soil measurements in each area were done at 100 points using a grid design with dimensions of $10 \mathrm{~m}$ long by $5 \mathrm{~m}$ wide. Soil sampling was taken from the $0.00-0.10 \mathrm{~m}$ layer, from points distributed along the planted row and the machine's wheel track. The following soil physical attributes were assessed: bulk density, total porosity, macroporosity, microporosity, soil penetration resistance, and water contentat field capacity. Bd and PR in the single-row spacing showed critical values for adequate sugarcane root development. The highest spatial variability of PR and Ma was found in double-row spacing, however, this spacing arrangement promoted a better soil physical conditions.

Keywords: bulk density; soil porosity; soil penetration resistance; soil water content; compaction.

\section{Introduction}

Sugarcane production in Brazil presents economic importance due to its production potential and climate adaptability. During the 2017/2018 sugarcane harvest, Brazil produced approximately 633 million tons (CONAB, 2018), coming first in worldwide production of sugarcane, and second in ethanol production (FAO, 2017). Fuel ethanol and electric energy generated from sugarcane bagasse are fundamental pillars in Brazil's energy matrix (Nyko et al., 2013).

In the majority of cultivated areas in Brazil, the sugarcane harvest is migrating from the use of traditional systems (manual harvesting of the whole cane) to a mechanized system, resulting in soil management changes, especially in relation to inter-row spacing. Reductions to sugarcane productivity have been attributed to excessive traffic near cultivation rows when using traditional spacing (row distance corresponding to machine wheel distance), which in turn leads to problems effecting root development and regrowth of plants (Braunack et al., 2006; Otto et al., 2011 Souza et al., 2015; Arcoverde et al., 2019). This scenario can be aggravated in areas where clayey soils are predominant (Morrison \& Gawander, 2016), especially if machine traffic occurs in conditions of inadequate soil moisture (Souza et al., 2015; Guimarães Júnnyor et al., 2019), which favor compaction (Reichert et al., 2009).
Geostatistical tools have been used to verify the spatial variability of soil physical attributes in order to better understand the changes promoted by traffic (Souza et al., 2010). In this sense, use of double spacing can minimize soil compaction near the cultivation row, improving the physical quality of the soil (Esteban et al., 2019; Scarpare et al., 2019). Castioni et al. (2019) accurately showed the spatial variability of soil physical attributes, and thereby assisted in the management of agricultural practices that directly affect the physical parameters of tropical weathered soils. The aim of this study was to evaluate the spatial variability of soil physical attributes on a clayey Oxisol under sugarcane cultivation using different row spacings, in order to determine the impact of harvesting traffic.

\section{Results and discussion}

\section{Soil physical attributes}

Table 1 shows the highest $\mathrm{Bd}$ and lower $\mathrm{Tp}$ and $\theta_{\mathrm{FC}}$ mean values in the single-row spacing, evidencing a poorer physical quality than the double-row spacing. Similar results were observed by Braunack and Mcgarry (2006), who obtained similarly lower Bd and PR values in double-row spacing $(0.3 \times 1.8 \mathrm{~m})$, compared to single-row spacing (1.5 m). In turn, Esteban et al. (2019) observed an increase of Ma 
in an Oxisol in sugarcane cultivation using a double-row spacing associated with controlled traffic. Although there was no significant difference, the PR presented a trend of lower values, and the Ma and Mi values presented a trend of higher values in the DR spacing when compared with SR spacing. Likewise, Mendes de Sousa et al. (2017), did not observe differences on PR, Ma and Mi values in a soil with sugarcane under single $(1.5 \mathrm{~m})$ and double-row $(0.9 \times 1.5 \mathrm{~m})$ spacing. In our study, the non-statistical difference between spacing was probably due to the organic matter contribution, reducing changes in soil structure and pore size (Reichert et al., 2009).

In the DR spacing Bd values of $1.40 \mathrm{Mg} \mathrm{m}^{-3}$ were observed (Table 1), similar to what was previously documented by Souza et al. (2004), also in an Oxisol under sugarcane cultivation. According to Reichert et al. (2003), in clayed soils $\mathrm{Bd}>1.40 \mathrm{Mgm}^{-3}$ is restrictive for most agricultural crops. Specifically in sugarcane, Vasconcelos et al. (2004) observed a restriction of root development in clayed soils (between $49-60 \%$ clay), with $\mathrm{Bd}$ values of $1.45 \mathrm{Mg} \mathrm{m}^{-3}$. In this sense, high $\mathrm{Bd}$ values in the SR spacing $\left(1.44 \mathrm{Mg} \mathrm{m}^{-3}\right)$ reflect the machines' excessive traffic, since the area was in its third year of mechanized harvesting.

Additionally, the critical PR value of $2.50 \mathrm{MPa}$ is considered also to be a restrictive physical attribute for root development in most crops (Camargo and Alleoni, 1997). As seen in Table 1, we observed the PR in SR spacing reach higher than critical values (2.68 MPa), whereas the PR in DR spacing was valued at 2.49 $\mathrm{MPa}$. Table 1 also shows the effect of machine traffic observed in relation to Ma values, which was lower in DR $\left(0.141 \mathrm{~m}^{3} \mathrm{~m}^{-3}\right)$, than in SR spacing $\left(0.127 \mathrm{~m}^{3} \mathrm{~m}^{-3}\right)$. According to Carvalho et al. (1991) and Reichert et al. (2009), Ma is the physical attribute most affected by soil compaction.

In both spacings the $\mathrm{Bd}, \mathrm{Tp}, \mathrm{Mi}$ and $\Theta_{\mathrm{FC}}$ values showed a lower variability $(<15 \%)$, while the $P R$ and Ma values showed a higher variability (<35\%). However, higher values of $\mathrm{Bd}$ (minimum of 0.96 and maximum of $1.77 \mathrm{Mg} \mathrm{m}^{-3}$ ), PR (minimum of 0.50 and maximum of $9.88 \mathrm{MPa}$ ), $\mathrm{Ma}$ (minimum of 0.031 and maximum of $0.348 \mathrm{~m}^{3} \mathrm{~m}^{-3}$ ) and $\theta_{\mathrm{FC}}$ (minimum of 0.298 of and maximum of $0.476 \mathrm{~m}^{3} \mathrm{~m}^{-3}$ ) were observed in DR spacing (Table 1 ). These results are possibly associated with the two zones in this type of spacing: (i) sugarcane root growth zone; (ii) machine traffic zone. In the machine traffic zone, high values of $\mathrm{Bd}$ and $\mathrm{PR}$, and low values of $\mathrm{Ma}$ and $\Theta_{\mathrm{FC}}$ can occur, and in the root growth zone these values are inverted, resulting in attributes with greater amplitudes. Similar results were observed by Souza et al. (2010) in an Oxisol under sugarcane cultivation.

\section{Spatial variability of soil physical attributes}

All analyzed soil attributes in the SR spacing presented spatial dependence (Table 2). The Bd, PR, Ma and TP values showed better semivariograms adjusted by the exponential type model, while the $\mathrm{Mi}$ and $\theta_{\mathrm{FC}}$ values showed better adjustment using the Gaussian model. Results agree with Souza et al. (2004) and Souza et al. (2010), who similarly observed spatial dependence between the variables $\mathrm{Bd}, \mathrm{Tp}$, $\mathrm{Ma}, \mathrm{Mi}$ and PR in sugarcane with SR spacing.

On the other hand, none of the soil attributes in the DR spacing presented spatial dependence, showing evidence of a pure nugget effect (Table 2).The absence of spatial dependence is probably associated with the occurrence of the two variation zones, as explained above. This caused the semivariance values to remain constant as the distance increased (range). However, when there was a distance increase between neighboring points, there should be a semivariance increase until reaching a sill where it would become invariant, indicating an unexplained variability, considering the sampling distance used. In this case, the study of structure of variability requires a sampling grid with greater area coverage, and/or numbered points (Webster and Oliver, 2007).

The $\mathrm{CO} /(\mathrm{CO}+\mathrm{C} 1)$ relationship showed strong spatial dependence for the PR, Mi and $\Theta_{\mathrm{FC}}$, and moderate spatial dependence for the $\mathrm{Bd}, \mathrm{Tp}$ and $\mathrm{Ma}$ attributes in SR spacing (Table 2), indicating that the semivariograms explain most of the attribute variance evaluated.

$\mathrm{Bd}$ presented the greater range $(31.29 \mathrm{~m})$, followed by $\mathrm{Mi}$, $\Theta_{\mathrm{FC}}, \mathrm{Ma}$ and $\mathrm{Tp}$, which presented ranges of $18.98 \mathrm{~m}, 18.45$ $\mathrm{m}, 10.95 \mathrm{~m}$ and $9.6 \mathrm{~m}$, respectively. All of these attributes in SR spacing showed greater reach, compared to the PR range, which presented a reach of $1.02 \mathrm{~m}$ (Table 2). The range differences between attributes could be due to the intrinsic spatial variability of each attribute, where the greatest range can be observed for those with lowest variability, i.e. with lower coefficient of variation ( $\mathrm{Bd}, \mathrm{Ma}, \mathrm{Mi}, \mathrm{\Theta}_{\mathrm{FC}}$ and $\mathrm{TP}$ ). PR was low-range due to one of the attributes most affected by the management of sugarcane agricultural systems (Carvalho et al., 1991). The knowledge of spatial dependence range allows the sampling radius definition to guarantee, in the next samplings and for the same conditions of this study, the independence of sampling points, the minimization of the mean standard error, and the sampling maximization.

The soil physical spatial distribution maps are presented in Figure 2. For $\mathrm{Bd}$, there is a region of high concentration between 1.55 and $1.49 \mathrm{Mg} \mathrm{m}^{-3}$, indicating a soil compaction zone in the SR spacing (Fig. 2a). In DR spacing, the majority of $\mathrm{Bd}$ values were between 1.41 and $1.33 \mathrm{Mgm}^{-3}$, with no defined region with high values (Fig. $2 b$ ), evidencing that sugarcane in DR spacing is more favorable to soil physical quality maintenance, and less susceptible to the soil structure changes caused by the machines traffic, corroborating with results previously found by Esteban et al. (2019).

Most of the area under SR spacing presented PR values between 2.41 and $4.04 \mathrm{MPa}$ (Fig. 2c), indicating an inadequate condition for root development, according to Bengough et al. (2011). Similar results in soils under sugarcane production were observed by Souza et al. (2006), where PR values ranged from 1.22 to $3.65 \mathrm{MPa}$, and by Roque et al. (2010), where PR values were 1.69 MPa in the row, and $3.03 \mathrm{MPa}$ in the wheel area of the machines.

In the DR spacing, the predominant PR value was $1.65 \mathrm{MPa}$ (Fig. 2d), showing better soil physical quality in relation to SR spacing, corroborating with results found by Esteban et al. (2019), who also observed improvement in soil physical conditions and yield of sugarcane in controlled traffic and DR spacing.

Greater Ma variability was obtained in the SR spacing, with predominant Ma values between 0.090 and $0.126 \mathrm{~m}^{-3} \mathrm{~m}^{-3}$ (Fig. 2e), while in DR spacing the Ma values were between 0.121 and $0.148 \mathrm{~m}^{-3} \mathrm{~m}^{-3}$ (Fig. 2f). These values indicate a beneficial effect of DR spacing in relation to soil porosity, agreeing with Mendes de Sousa et al. (2017), and Esteban et al. (2019). In SR spacing, regions with the highest Ma values (Fig. 2e) coincide with the same regions with the lowest $B d$, PR and Mi values (Fig. 2a,c,g, respectively). 
Table 1. Mean value, maximum and minimum values, standard deviation and coefficient of variation (CV) of soil physical attributes with sugarcane crop under different row spacing $(n=100)$.

\begin{tabular}{|c|c|c|c|c|c|c|c|}
\hline Attributes & Spacing $^{1}$ & Mean* & Median & Minimum & Maximum & SD & CV (\%) \\
\hline $\mathrm{Bd}$ & SR & $1.44 \mathrm{a}$ & 1.46 & 1.13 & 1.72 & 0.14 & 9.6 \\
\hline$\left(\mathrm{Mgm}^{3}\right)$ & DR & $1.40 \mathrm{~b}$ & 1.41 & 0.96 & 1.77 & 0.15 & 10.6 \\
\hline PR & SR & $2.68 a$ & 2.36 & 0.53 & 7.42 & 1.49 & 55.8 \\
\hline (MPa) & DR & $2.49 a$ & 2.17 & 0.50 & 9.88 & 1.56 & 62.7 \\
\hline $\mathrm{Tp}$ & SR & $0.539 \mathrm{~b}$ & 0.533 & 0.467 & 0.701 & 0.038 & 7.1 \\
\hline$\left(m^{3} m^{-3}\right)$ & DR & $0.561 \mathrm{a}$ & 0.552 & 0.496 & 0.677 & 0.038 & 6.7 \\
\hline $\mathrm{Ma}$ & SR & $0.127 a$ & 0.111 & 0.039 & 0.291 & 0.054 & 42.3 \\
\hline$\left(m^{3} m^{-3}\right)$ & DR & $0.141 \mathrm{a}$ & 0.122 & 0.031 & 0.348 & 0.065 & 46.3 \\
\hline $\mathrm{Mi}$ & SR & $0.412 \mathrm{a}$ & 0.417 & 0.318 & 0.481 & 0.032 & 7.9 \\
\hline$\left(\mathrm{m}^{3} \mathrm{~m}^{-3}\right)$ & DR & $0.420 \mathrm{a}$ & 0.421 & 0.322 & 0.485 & 0.033 & 7.9 \\
\hline$\theta_{\mathrm{FC}}$ & SR & $0.388 \mathrm{~b}$ & 0.392 & 0.293 & 0.454 & 0.034 & 8.7 \\
\hline$\left(m^{3} m^{-3}\right)$ & DR & $0.404 \mathrm{a}$ & 0.406 & 0.298 & 0.476 & 0.037 & 9.0 \\
\hline
\end{tabular}

SR: Single-row spacing (1.5 m); DR: Double-row spacing (0.4 × $1.5 \mathrm{~m})$; SD: standard deviation; CV: coefficient of variation; Bd: bulk density; PR: soil penetration resistance; Tp: Total porosity; Ma: Macroporosity; Mi: Microporosity; $\Theta_{\mathrm{FC}}$ : water contentat field capacity; *Means followed by the same letter in the column in the row do not differ by Tukey's test ( $\left.\mathrm{p} \leq 0.05\right)$.

a)

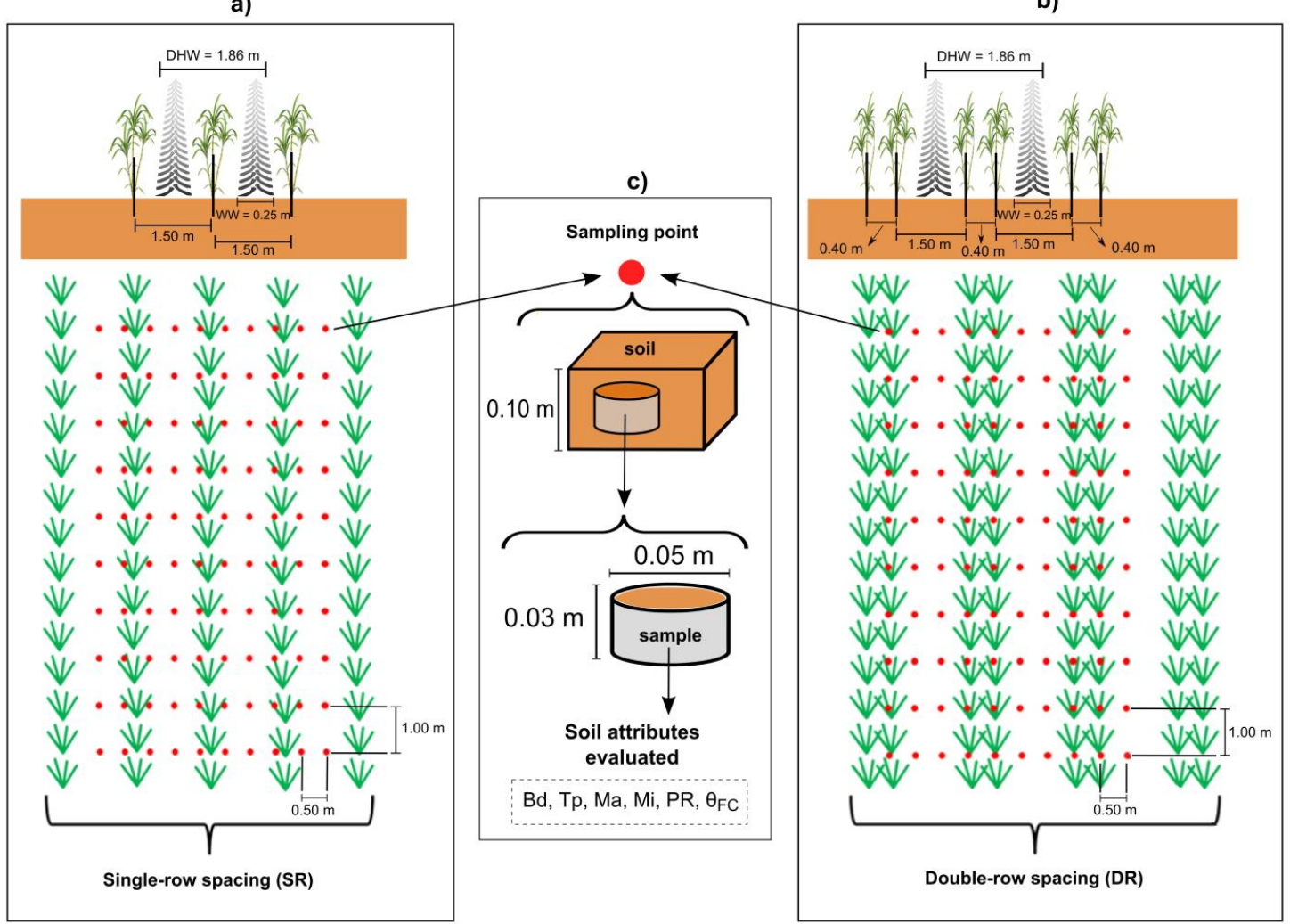

Fig. 1. Distribution of measurement points (in red) for soil properties in the single-row (a), and double-row spacing (b) of an Oxisol under sugarcane production.

DHA = distance between harvester wheel; WW = wheel width. Bd: bulk density; Tp: Total porosity; Ma: macroporosity; Mi: microporosity; PR: soil penetration resistance; $\theta$ FC: water contentat field capacity.

Table 2.Estimated models and parameters of experimental semivariograms of soil physical attributes with sugarcane crop under different row spacings $(n=100)$.

\begin{tabular}{lcccccccc}
\hline Attributes & Spacing & Model & $\mathrm{R}^{2^{*}}$ & $\mathrm{RSS}^{* *}$ & Range (a) & Sill $\left(\mathrm{C}_{0}+\mathrm{C}_{1}\right)$ & Nugget Efect $\left(\mathrm{C}_{0}\right)$ & $\mathrm{C}_{0} /\left(\mathrm{C}_{0}+\mathrm{C}_{1}\right)^{1}$ \\
\hline $\mathrm{Bd}$ & $\mathrm{SR}$ & Exponential & 0.68 & $4.45 \times 10^{-5}$ & 31.29 & 0.0436 & 0.0119 & - \\
$\left.(\mathrm{Mgm})^{3}\right)$ & $\mathrm{DR}$ & $\mathrm{PNE}^{2}$ & - & - & - & - & - & - \\
$\mathrm{PR}$ & $\mathrm{SR}$ & Exponential & 0.26 & 0.414 & 1.02 & 2.2830 & 0.2930 & - \\
$(\mathrm{MPa})$ & $\mathrm{DR}$ & $\mathrm{PNE}$ & - & - & - & - & - & - \\
$\mathrm{Tp}$ & $\mathrm{SR}$ & Exponential & 0.76 & $1.41 \times 10^{-7}$ & 9.60 & 0.0020 & 0.0009 & - \\
$\left(\mathrm{m}^{3} \mathrm{~m}^{-3}\right)$ & $\mathrm{DR}$ & $\mathrm{PNE}$ & - & - & - & - & - & - \\
$\mathrm{Ma}^{*}$ & $\mathrm{SR}$ & Exponential & 0.73 & $1.03 \times 10^{-6}$ & 10.95 & 0.0076 & 0.0017 & - \\
$\left(\mathrm{m}^{3} \mathrm{~m}^{-3}\right)$ & $\mathrm{DR}$ & $\mathrm{PNE}$ & - & - & - & - & - & - \\
$\mathrm{Mi}^{3}$ & $\mathrm{SR}$ & Gaussian & 0.82 & $1.81 \times 10^{-7}$ & 18.98 & 0.0063 & 0.0007 & - \\
$\left(\mathrm{m}^{3} \mathrm{~m}^{-3}\right)$ & $\mathrm{DR}$ & $\mathrm{PNE}$ & - & - & - & - & - & - \\
$\theta_{\mathrm{FC}}$ & $\mathrm{SR}$ & Gaussian & 0.77 & $2.47 \times 10^{-7}$ & 18.45 & 0.0060 & 0.0008 & 13 \\
$\left(\mathrm{~m}^{3} \mathrm{~m}^{-3}\right)$ & $\mathrm{DR}$ & $\mathrm{PNE}$ & - & - & - & - & - & 13
\end{tabular}

SR: Single-row spacing (1.5 m); DR: Double-row spacing (0.4 x 1.5 m); SD: standard deviation; CV: coefficient of variation; Bd: bulk density; PR: soil penetration resistance; Tp: Total porosity; Ma: Macroporosity; Mi: Microporosity; $\Theta_{\mathrm{FC}}$ : water contentat field capacity; ${ }^{1}$ Spatial dependence degree; ${ }^{2} \mathrm{PNE}=$ pure nugget effect; ${ }^{*} \mathrm{R}^{2}$ :determination coefficient; ${ }^{* *} \mathrm{RSS}:$ residual squared sum. 

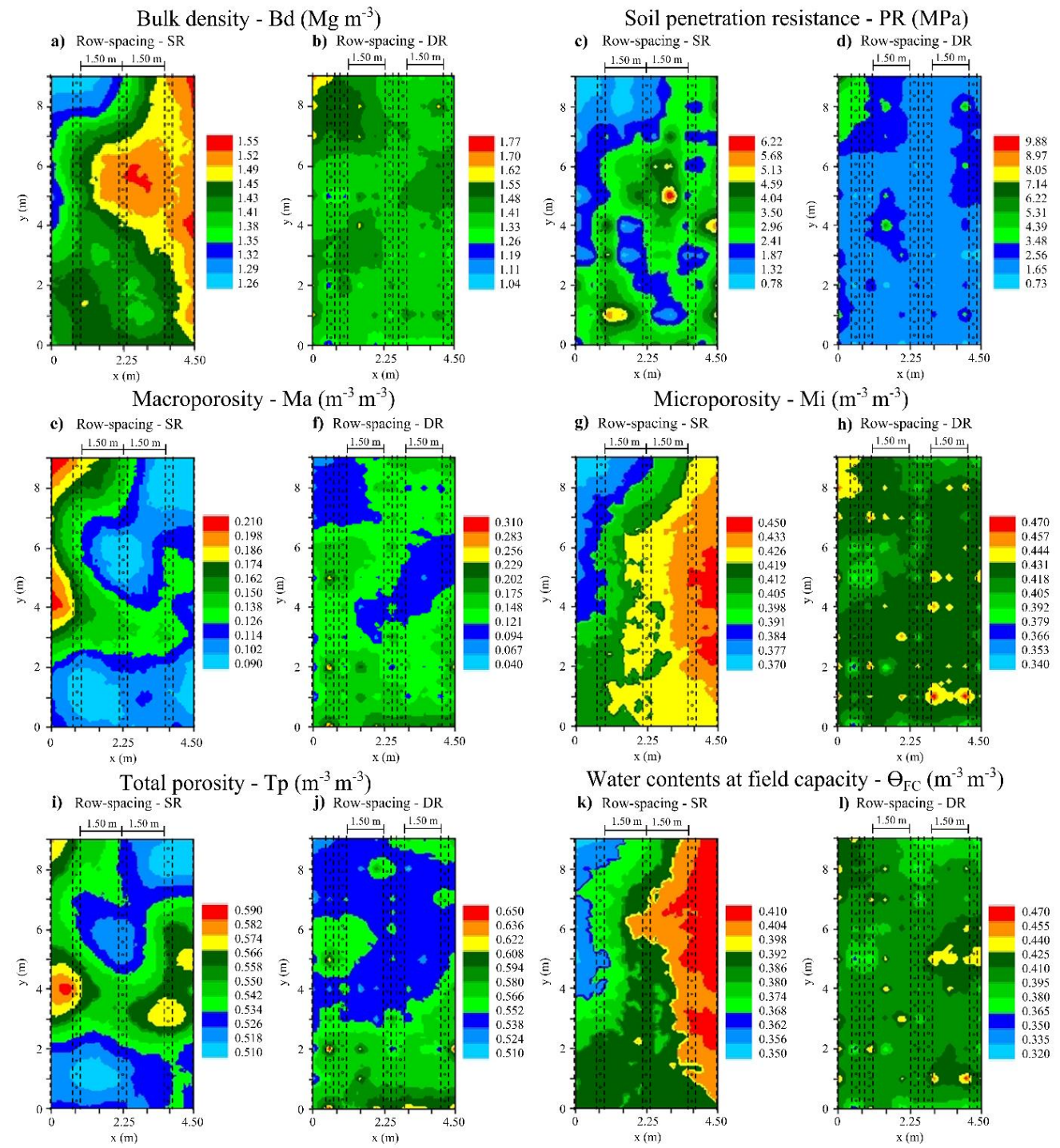

Fig. 2. Spatial distribution of soil physical attributes with sugarcane crop under single-row (SR) and double-row (DR) spacing.

Similar behavior was observed for Mi values in SR spacing (Fig. 2g), which showed higher variability than in DR spacing (Fig. 2h). Regions with higher Mi (Fig. 2g) and water content in the field capacity (Fig. 2k), coincide with higher Bd regions (Fig. 2a) in SR spacing. This variability in Ma and Mi values, mainly in the SR spacing, was reflected in Tp values (Fig. 2i,j). These results are related to the compaction process, where air and water are expulsed, leading to a reduction in soil volume and resulting in a higher Bd. According to Reichert et al. (2009), this greater proximity of particles promotes an increase in cohesion forces, resulting in a reduction of larger diameter pores (macropores), and an increase of the smaller pores (micropores). Regarding $\theta_{\mathrm{FC}}$ values (Fig. 2k), we observed a behavior similar to that observed in microporosity, probably due to the sharing of the same causes of variation. For water potentials equal to and greater than the field capacity, there was an increase of the water content retained in compacted soils, probably associated with a higher microporosity, which favors the capillarity process. Similar results were found by Stone et al. (1994), who evaluated physical and hydraulic attributes in a clayey Oxisol, and concluded a reduction in available water in the superficial layer after seven successive crops under a central pivot. Finally, spacing management in sugarcane cultivated in clayey soil mainly influences the superficial layer of soil, with higher changes seen in the Bd and PR attributes which are reflected in the distribution of the size

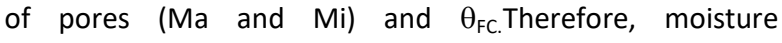
monitoring before machine traffic commences is recommended to minimize compaction (Guimarães Júnnyor et al., 2019), as well as maintaining soil cover by vegetal residues, which can dissipate the compaction energy caused by the contact between the soil and the machine's wheels (Silva et al., 2016).

\section{Materials and methods}

\section{Study area}

The experiment was carried out in Porto Xavier country $\left(27^{\circ} 53^{\prime} 00,15^{\prime \prime} \mathrm{S}\right.$ and $\left.55^{\circ} 12^{\prime} 07,25^{\prime \prime} \mathrm{W}\right)$, Rio Grande do Sul state, Southern Brazil. The climate in this region is classified as humid subtropical ( $\mathrm{Cfa}$ ) with hot summers and distributed rains throughout the year (Alvares et al., 2013). The soil was classified as Oxisol with clayey texture (60\% clay; $17 \%$ silt and $17 \%$ sand), and $1 \%$ of total organic carbon at $0.30 \mathrm{~m}$ depth.

\section{Treatments}

Two areas of sugarcane production (RB855156 genotype) were planted in autumn 2013, both using conventional planting systems, with pieces of stalk (setts) planted directly 
into the soil. Treatments were either sugarcane cultivated using: (i) single-row spacing (SR) of $1.50 \mathrm{~m}$; or (ii) double-row spacing (DR) of $0.40 \times 1.50 \mathrm{~m}$. Areas using SR spacing occupied a total of 6 ha, area using DR spacing occupied a total of 2 ha.

The sugarcane was harvested using an Austoft 7000 sugarcane harvester, with a distance between wheels of $1.86 \mathrm{~m}$ and $\mathrm{a}$ wheel width of $0.25 \mathrm{~m}$ (Fig. 1).

\section{Soil samples}

Assessments of soil physical attributes were performed during the summer of 2016 after the second harvest. Soil measurements in each area were done at 100 points using a grid design with dimensions of $10 \mathrm{~m}$ long by $5 \mathrm{~m}$ wide. Soil sampling was taken from the $0.00-0.10 \mathrm{~m}$ layer; from points distributed along the planted row and the machine's wheel track (Fig. 1). The following soil physical attributes were assessed: bulk density (Bd), total porosity (Tp), macroporosity (Ma), microporosity (Mi) (methodology by Teixeira et al., 2017), soil penetration resistance (PR) (methodology by Bradford, 1980) and water contentat field capacity $\left(\theta_{\mathrm{FC}}\right)$ (methodology by Klute, 1986).

\section{Statistical analysis}

Basic statistical parameters i.e. the mean value, standard deviation, coefficient of variation (CV), and the maximum and minimum values for soil properties were determined. We used the coefficient of variation classification proposed by Wilding and Dress (1983), where CV <15\% corresponded to lower variability, $15 \% \leq \mathrm{CV}<35 \%$ mean variability and CV $\geq 35 \%$ corresponding to high variability.

The spatial dependence and variation of the quantities were studied with the help of semivariograms (Vieira, 2000). Semivariance estimation was used following the methodology proposed by Matheron (1962) where the linear, spherical, exponential and Gaussian semivariograms were adjusted using the software GS+ (Gamma Design, 2012). Criterion to define the better model used the crossvalidation technique, where the estimated values were related to the values sampled by linear regression. Two parameters of regression analysis were adopted to verify the model quality: (i) residual squared sum (RSS); (ii) determination coefficient $\left(R^{2}\right)$. Cambardella et al. (1994) classification was used to analyze the degree of the attributes' spatial dependence: (i) strong spatial dependence with nugget effect $<25 \%$, moderate spatial dependence with nugget effect between 25 and $75 \%$, and weak spatial dependence with nugget effect $>75 \%$. For variables with spatial dependence, the ordinary kriging method was used to interpolate the values and to make the maps. The distance square inverse method was used for variables with no spatial dependence.

Descriptive statistics analyzes were performed using $R$ Software (R Core Team, 2019).

\section{Conclusions}

$\mathrm{Bd}$ and $\mathrm{PR}$ in the single-row spacing showed critical values for adequate sugarcane root development.

The highest spatial variability of PR and Ma was found in double-row spacing, however, this spacing arrangement also promoted a better soil physical conditions.

\section{Acknowledgements}

The authors wish to thank the Federal University of Pelotas, EMBRAPA Temperate Climate, COOPERCANA from Porto Xavier city, FINEP and PETROBRAS.

\section{References}

Alvares CA, Stape JL, Sentelhas PC, de Moraes Gonçalves JL, Sparovek G (2013) Köppen's climate classification map for Brazil. Meteorol Z. 22:711-728.

Arcoverde SNS, Souza CM, Cortez JW, Maciak PAG, Suárez AHT (2019) Soil physical attributes and production components of sugarcane cultivars in conservationist tillage systems. Eng Agric. 39:216-224.

Bengough AG, Mckenziel BM, Hallett PD, Valentine TA (2011) Root elongation, water stress, and mechanical impedance: a review of limiting stresses and beneficial root tip traits. J Exp Bot. 62:59-68.

Bradford JM (1980) The penetration resistance in a soil with well-defined structural units. Soil Sci Soc Am J. 44:601-606.

Braunack M V, Mcgarry D (2006) Traffic control and tillage strategies for harvesting and planting of sugarcane (Saccharum officinarum) in Australia. Soil Till Res. 89:86102.

Castioni GAF, de Souza ZM, Nazário AA, Borges BMMN, Torres JLR, Dayron MRS, Campos MCC (2019) Variability of physical attributes in tropical weathered soil cultivated with irrigated beans (Phaseolus vulgaris L.) Aust J Crop Sci. 13:656-661.

Camargo AO, Alleoni LRF (1997) Compactação do solo e desenvolvimento das plantas. ESALQ, Piracicaba.

Cambardella CA, Moorman TB, Parkin TB, Karlen DL, Novak JM, Turco RF, Konopka AE (1994). Field-scale variability of soil properties in central lowa soils. Soil Sci Soc Am J. 58:1501-1511.

Carvalho SR, Bruand A, Hardy M, Leprum JC, Jamagne M (1991) Tassement des sols ferrallitiques Podzólico Vermelho Amarelo sous culture de canne à sucre (état de Rio de Janeiro, Brézil): apport d'une analyse de la porosité associée a une connaissance détaillée de la phase minérale. Cah Orstom Sér Pedol. 26:195-212.

Conab - Companhia nacional de abastecimento (2018) Acompanhamento da safra brasileira de cana-de-açúcar. SAFRA 2017/18 - Quarto levantamento. Monitoramento Agrícola. Esteban DAA, de Souza ZM, Tormena CA, Lovera LH, de Souza Lima E, de Oliveira IN, de Paula Ribeiro N (2019). Soil compaction, root system and productivity of sugarcane under different row spacing and controlled traffic at harvest. Soil Till Res. 187:60-71.

Fao - Food and Agriculture Organization of United Nations (2017) Countries by commodity.

Guimarães Júnnyor WS, de Maria IC, Araujo-Junior CF, Lima CC, Vitti AC, Figueiredo GC, Dechen SCF (2019) Soil compaction on traffic lane due to soil tillage and sugarcane mechanical harvesting operations. Sci Agr. 76:509-517.

Gamma Design Software (2012). GS+: Geostatistics for the Environmental Sciences. Gamma Design Software. Plainwell, Michigan.

Klute A (1986) Water retention: laboratory methods. In: Black CA (ed) Methods of Soil Analysis. I. Physical and mineralogical methods. American Society of Agronomy, Soil Science Society of America, Madison.

Matheron G (1962) Traité de géostatistiqueappliquée. TECHNIP. Paris, 14. 
Mendes de Sousa, ACM, Menezes de Souza Z, Poch RM, Rodrigues Torres JL (2017) Traffic control with autopilot as an alternative to decrease soil compaction in sugarcane areas. Trop Subtrop Agroecosyst. 20:173-182.

Morrison RJ, Gawander JS (2016) Changes in the properties of Fijian Oxisols over 30 years of sugarcane cultivation. Soil Res. 54: 418-429.

Nyko D, Valente MS, Milanez AY, Tanaka AKR, Rodrigues AVPR (2013) A evolução das tecnologias agrícolas do setor sucroenergético: estagnação passageira ou crise estrutural? Rio de Janeiro, BNDS-Documentos, 37.

Otto R, Silva AP, Franco HCJ, Oliveira ECA, Trivelin PCO (2011) High soil penetration resistance reduces sugarcane root system development. Soil Till Res. 117:201-210.

R Core Team (2019) R: A language and environment for statistical computing. $\mathrm{R}$ Foundation for Statistical Computing, Vienna.

Reichert JM, Suzuki LEAS, Reinert DJ, Horn R, Håkansson I (2009) Reference bulk density and critical degree-ofcompactness for no-till crop production in subtropical highly weathered soils. Soil Till Res.102:242-254.

Reichert JM, Reinert DJ, Braida JA (2003) Qualidade dossolos e sustentabilidade de sistemas agrícolas. Ci Amb. 27:29-48

Roque AA O, Souza ZM, Barbosa RS, Souza GS (2010) Controle de tráfego agrícola e atributos físicos do solo em área cultivada com cana-de-açúcar. Pesq Agropec Bras. 45:744-750.

Silva RBD, lori P, Souza ZMD, Pereira DDMG, Vischi Filho OJ, Silva FADM (2016) Contact pressures and the impact of farm equipment on Latosol with the presence and absence of sugarcane straw. Ciênc Agrotec. 40:265-278.

Souza GSD, Souza ZMD, Cooper M, Tormena CA (2015) Controlled traffic and soil physical quality of an Oxisol under sugarcane cultivation. Sci Agric. 72:270-277.
Souza ZM, Júnior JM, Pereira GT (2010) Geoestatística e atributos do solo em áreas cultivadas com cana-de-açúcar. Cienc Rural. 40:1-10.

Souza ZMD, Campos MCC, Cavalcante ÍHL, Marques Júnior J, Cesarin LG, Souza SRD (2006) Dependência espacial da resistência do solo à penetração e do teor de água do solo sob cultivo contínuo de cana-de-açúcar. Cienc Rural. 36:128-134.

Souza ZM, Marques Júnior J, Pereira GT (2004) Variabilidade espacial de atributos físicos do solo em diferentes formasdo relevo sob cultivo de cana-de-açúcar. Rev Bras de Cienc

Solo. 28:937-944.

Scarpare FV, van Lier QDJ, de Camargo L, Pires RCM, RuizCorrêa ST, BezerraAHF, Dias C TDS (2019) Tillage effects on soil physical condition and root growth associated with sugarcane water availability. Soil Till Res. 187:110-118.

Teixeira PC, Donagemma GK, Fontana A,Teixeira WG (2017) Manual de métodos de análise de solos. 3rd ed. Brasília.

Vasconcelos AD, Prado H, Landell MGA (2004) Desenvolvimento do sistema radicular da cana-de-açúcar e características físico-hídricas e químicas dos ambientes de produção. Adonis. Americana.

Vieira SR (2000) Geoestatística em estudos de variabilidade espacial do solo. In: Novais RF, Alvarez VVH, Schaefer GR (ed).Tópicos em Solos. Sociedade Brasileira de Ciência do Solo, Viçosa. 1.

Webster R, Oliver MA (2007) Geostatistics for environmentalscientists. John Wiley \& Sons.

Chichester.

Wilding LP, Dress LR (1983) Spatial variability and pedology. In: Wilding LP, Smeck NE, Hall GF(eds) Pedogenesis and soil taxonamy: concepts and interactions. New York. 